\title{
Take up Position: Defining Industrial Design in Postwar Belgium (1954-1970)
}

Countless definitions of design have been formulated throughout history, and they have often been subject of much controversy, revealing consciously or unconsciously, a specific agenda or certain convictions. This paper examines how 'design' was understood when this term took root in Belgium and was appropriated by official circles in the postwar area. It tracks the search of state-related design institutions for an adequate definition and outlines their positioning in design networks. This paper then argues that the institutional foundations of Belgian design in the economic and industrial sector of the 1950 continued to influence its official understanding until the 1970s. However, influenced by international tendencies, the official design bodies struggled to break design loose of its economic base and get it recognized as a cultural and social phenomenon by the Belgian government. This paper draws on newly found archival records, adding new insights to existing accounts on Belgian design policies.' By examining the state-backed definition, this paper is not so much interested in the etymology of the English term 'design', but rather on how the Belgian state accentuates certain aspects of this concept in their policy shaping certain understandings of design. ${ }^{2}$ In sum, this casus wants to provide an entry to map different processes that were important in postwar Belgium: (a) the role of the institutional framework in the formation of definitions and understandings of design, (b) the interaction between the discipline of design and the process of design institutionalization and (c) the influence of transnational and global networks in the creation of national design cultures.

keywords postwar design, definition industrial design, Belgium, design centre, design policies

\section{Exploring the field at the crossroads of Europe (1954-1963)}

How has a small country at the crossroads of Europe had to define this new phenomenon of industrial design? Although one of the first pioneers of industrial design in the beginning of the 2oth century was the Belgian Henry van de Velde, the movement only took root in 1954 under the reign of the first social-liberal government. The kick-off

\footnotetext{
'The work of Javier Gimeno-Martínez (2011, 2010b, 2010a, 2007) addresses the relation between the Belgian state and design and the construction of national design identities. The design historian Fredie Floré (2010) studies design organizations that focused on furniture design and that were rather located outside the institutional framework. Other literature only provides an introductory account on design policies in Belgium (Coirier 2004; Bucqoye, Daenens, and De Kooning 2001).

${ }^{2}$ In this regard, the project Words for design edited by Fujita (2007-2009) proves to be vary valuable. Although the emphasis is put on the etymology of 'design' and similar vernacular terms, it also touches upon the adoption of the term in official policies.
} 
was the speech of the Minister of Education, Pierre Harmel, in Liège3. The speech was titled "La Laideur se vend mal", inspired by the title of the American bestseller of Raymond Loewy. Pierre Harmel regretted the considerable arrears of Belgium with regard to industrial design and stimulated the start of a new movement to make up the lost ground. In the formative years, this movement was composed mainly of industrials and policymakers who stood in close contact with leading figures of neighboring design scenes such as Henry van de Velde in Switersland, Jacques Viénot in France, Karel Sanders in the Netherlands and Paul Mahlberg in Germany. Originally initiated in Liège, the movement was relocated in Brussels in 1956 when it got official recognition of the Ministry of Economy and its definitive name: Institute for Industrial Design for Belgium and the Grand Duchy of Luxembourg. In its first documents of 1956, they define Industrial design as:

"The art and science to create or improve industrial products considering all the elements - technical, functional, commercial and aesthetical - who are capable of increasing the sales by the reduction of the cost price, of adapting the object to its function and especially of the aesthetic creation of the forms, the lines and the colors that pleases the eye and adds to its total unity". ${ }^{4}$

In 1957, one sentence is added to this definition: "This improved design will augment the sales on the Belgian and foreign markets" " Het Instituut voor Industriële Vormgeving" 1957). This added sentence reveals the economic concerns about the growing liberalization in light of the European Economic Community (EEC) or Common Market (Gimeno-Martínez 2010b). These new economic challenges, together with the prospect of the organization of the Brussels world fair in 1958, forced Belgium to take up a position in the realm of design. Roughly, we can discern three strands that dominated the first Belgian debates: the Dutch, the French and the American. In the frame of this short paper, only the last two will be shortly touched upon.

The French strand of influence was especially represented by the French Institute for Industrial Design that was created in 1951 and headed by Jacques Viénot (19201960). In 1952, this institute published a chart that defined industrial design as "the science of beauty"(Le Boeuf 2006). The aesthetical in this definition was understood as philosophical discipline that was base on the idea by Paul Souriau (1825-1926) which was closely linked to modernist thinking on harmony of beauty and function (Maldonado 1962). In Belgium, this definition got contradictory reactions. Pol Provost, director of the Belgium firm De Coene, and later an important design personality as president of the Belgian Institute of Industrial Design and the Design Centre, was of the opinion that the French vision came the most close to an ideal definition. Yet, many misunderstood the "aesthetical" because of its associations with superficial decoration and rejected this definition. One of the most influential strands that dominated the early stage of the Belgian debate was the American. This is not surprising since the Marshall plan initiated a productivity campaign in Europe, facilitating the wide spread of American design ideas. American design was in general associated with marketing research and product development. The most important followers in Belgium then of this approach were economic and industrial organizations. Yet, for many American industrial design was a counterexample (Crowley

\footnotetext{
${ }^{3}$ Brussels, Archives \& Musée de la Litérature, Fonds Henry van de Velde, 211/15: Maurice Paquay, Association Belge des industrial designers. Historique des débuts de l'association. ${ }^{4}$ Brussels, Archives \& Musée de la Litérature, Fonds Henry van de Velde, 211/14: Association Belge des Industrial Designers. L'Esthétique Industrielle en Belgique.
} 
and Pavitt 2008, 10-71), and this was also the case in Belgium. Harsh critique came from Pol Provost. He criticized that the definitions inspired by the American practice considered the product only as an sales element and neglect the social and aesthetical elements (Provost 1959).

In sum, the discussions above were primarily conducted by actors - politicians, industrials and organizations - linked to the sphere of economics, trade and export. Although these discussions illustrate the complex and layered positioning of design in Belgium, the economic aspect was primordial in the formulation of definitions. In 1959 the Minister of Economic Affairs even centralized all the activities concerning industrial design in his department (Van der Schueren 1959). However, in 1960, Maurits Van Haegendoren (1903-1994), the president of the Lodewijk de Raet foundation will address this as a problematic issue. He accused the institute to ignore completely the social and cultural aspects of design. ${ }^{5}$ He stated: "industrial design is not only a question of 'sales promotion' but also about the education of the consumer taste." With this critique, Van Haegendoren anticipates on the developments of design promotion in the next decade.

\section{Attempts to establish a national doctrine (1964-1970): The Brussels Design Centre}

After an ideological exploration, the official definition finally took a definitive shape when a new design institution loomed up: the Design Centre. It was established in 1964 with help of the Belgian Institute for industrial design under the protection of the Belgian Office for Foreign Trade and financed by the Ministry of Economic Affairs, and later by the Belgian Office for Increasing Productivity. ${ }^{6}$ The board was composed mainly of industrials and policy officials. The already existent institute and the new Design Centre were supposed to function as a 'tandem' ("Een Design Centre te Brussel" 1963). The institute had to promote industrial design in the Belgian industry, and the Design Centre had to make sure it was fruitful through the export of Belgian design. To do this, the center organized a permanent exhibition of 'good' Belgian products, temporary thematic exhibitions, award competitions and conferences. Most of these activities took place in the exhibition space located in the heart of Brussels between the commercial and the business district. From the very beginning they adopted the definition formulated in 1964 by the Argentinian Thomás Maldonado, then rector of the famous Hochschule für Gestaltung:

"Industrial design is a creative activity whose aim is to determine the formal qualities of objects produced by industry. These formal qualities are not only the external features but are principally those structural and functional relationships which convert a system to a coherent unity both from the point of view of the producer and the user. Industrial design extends to embrace all the aspects of human environment which are conditioned by industrial production."

By adopting this international definition, the Design Centre seemingly responded to previous critiques by including the user as important factor in the understanding of

\footnotetext{
${ }_{5}^{5}$ Ghent, Design Museum Gent, Museum Archives, unnumbered: Proces-Verbaal van de 1ode vergadering der werkgroep voor de studie van de Industriële Vormgeving, gehouden in het Instituut voor Industriële Vormgeving op 7 december 1960 .

${ }^{6}$ The proliferation of Design Centres was a worldwide phenomenon. The Brussels Design Centre had one of the longest track records among such centers (22 years) and was established after the model of the British Design Centre in London. The Greek, New Zealand, Norwegian cases show similarities with the Belgian case. All are established out of commercial or economic reasons and present industrial design as an economic matter. See (Woodham 2010; Yagou 2005; Thompson 2011; Fallan 2007)
} 
design. It emphasized the humanistic aims of design to conciliate the producer and user.

Moreover, the Design Centre kept on enlarging the field of design to fashion, electronics, public infrastructure and city planning. However, next to this renewed vision, old ideals from the previous phase of design promotion still continued to influence the Design Centre's policy. The selection criteria for 'good' design -technical quality, functional value, aesthetics, reasonable price and creativity- were similar to the criteria used by the promotional institutions in the 1950 (Gimeno-Martínez 2010b). The design critic K.N. Elno disapproved with this practice. In 1974, he looked back to ten years design promotion and accused the center to have realized old ideals at the eve of a new area that would be characterized by the revolution of May 68 and the 'beatle' generation that reintroduced the ornament (Bekker and Dutreeuw 1974).

The Design Centre's policy intended to initiate a new and enlarged understanding of design as economic, social and cultural phenomenon. However, it was in some cases unable to leave behind the origins of design promotion dominated by national export interests. This had much to do with the divergent agenda of its Maecenas. This was strongly manifested in the design vision of the Belgian Office for Increasing Productivity (BDOP) that financially supported the Design Centre. The BDOP was established in the beginning of the 1950 s with US funding as part of the Marshall-plan and was after 1956 financed by the Belgian government. Its aim was to increase the Belgian productivity equal to US standards. In short, the BDOP demanded a practical definition of design applicable for increasing the national economic performance, expressed in terms of economic efficiency and innovation, and situated in the realm of the Belgian enterprises. These convictions, supported by a large part of the Belgian industry, seem to persist with the American strand.

Inspired by international tendencies, the Design Centre struggled to break design loose of its economic base and get it recognized as a cultural and social phenomenon by the Belgian government. Already in 1969 the Institute for Industrial Design demanded attention from the Ministries of Culture for design as an exponent of the national cultural level (Provost 1969). However, this question was without effect and design activities were rarely supported by cultural bodies. The reason was that design was not seen as something "typically cultural". 7 This attitude offended the organizers because they believed that "after all, this [design] is the most visible and pervasive cultural manifestation of any country at any time."

Concerning the social aspirations, the Design Centre worked together in 1977 with the Ministry of Public works in order to humanize the public environment by design. ${ }^{8}$ In relation to these activities, design was defined as "profoundly human". Although, this attests of a social concern, since the Design Centre was financed by the BDOP and the Belgian Office for Foreign Trade it was always paired with an economical one, in this case it was the improvement of the national image and export.

In conclusion, the state constructs images and discourses on design by its promotion, using expertise from the discipline of design, however. Yet the meaning of design - as promoted by the state - depends on how the latter instrumentalizes design: as a tool

\footnotetext{
7 Brighton, University of Brighton, Design Archives, Council of Industrial Design, box 157: Josine des Cressonnières, Letter to Paul Reilly (18/8/1872)

${ }^{8}$ Brussel, Design Vlaanderen, Documentatiecentrum, Fonds Design Centre, Doos 16 'Design pour l'Etat': Interministeriële Designcommissie, [Octobre 1981].
} 
to improve economic performance, as a humanistic expression, or as a cultural representation. In the Belgian case, design had difficulties to break free from the economic base where it was first institutionalized and gain social and cultural recognition of the state.

\section{References}

Bekker, Ludo, and Kaat Dutreeuw. 1974. 10 jaar Design Center. In Kortweg: VRT (Vlaamse Radio- en Televisieomroeporganisatie).

Bucqoye, Monique, Lieven Daenens, and Mil De Kooning. 2001. Forms from Flanders. From Henry van de Velde t.o. Maarten van Severen 1900-2000. Gent/Amsterdam: Ludion. Coirier, Lise. 2004. Design en Belgique/in Belgium/ in België 1945-2000. Brussels: Racine. Crowley, David, and Jane Pavitt. 2008. Cold War Modern. Design 1945-1970. London: V\&A Publishing. "Een Design Centre te Brussel." 1963. Informatieblad van het Instituut voor Industriële Vormgeving no. 6 (2):9-10.

Fallan, Kjetil. 2007. "How an Excavator Got Aesthetic Pretentions - Negotiating Design in 196os' Norway." Journal of Design History no. 20 (1):43-59.

Floré, Fredie. 2010. Lessen in goed wonen. Woonvoorlichting in België 1945-1958. Leuven: Universitaire Pers Leuven.

Fujita, Haruhiko. 2007-2009. Words for Design. Comparative Etymology and Terminology of Design and Its Equivalents. The First Step Towards a Full Collection of Words for Design from All over the World. 3 vols.

Gimeno-Martínez, Javier. 2007. "Selling Avant-garde: How Antwerp Became a Fashion Capital (1990-2002)." Urban Studies no. 44 (12):2449-2464.

- - . 2010a. "Industrial Design in the Museum. The Case of the FN Milking Machine (ca.

1947)." The Burlington Magazine no. 152 (1290):603-608.

- - 2010b. "The Signe d'Or Award Scheme from 1956 to 1960: The Economic Reasons for "Good Design"." Konsthistorisk Tikskrift / Journal of Art History no. 79 (3):127-145. -_-. 2011. "Redefining Social Design in 1970 Belgium: Affordable Design vs. Elite Design." Interiors no. 2 (2):149-168.

"Het Instituut voor Industriële Vormgeving." 1957. Berichten van het Insituut voor Industriële Vormgeving (1).

Le Boeuf, Jocelyne. 2006. "Jacques Viénot and the "Esthétique Industrielle" in France (1920-1960)." Design Issues no. 22 (1):46-63.

Maldonado, Tomas. 1962. "Comments. From Homer to Raymond Loewy." Ulm (6):26-27. Provost, Pol. 1959. "Bedrijfsleiding en Industriële Vormgeving." In Industriële Vormgeving (1957-1958), edited by Stichting Lodewijk De Raet, 55-68. Brussels: Stichting Lodewijk De Raet.

- - . 1969. "Industriële vormgeving is ieders zaak." Het Laatste Nieuws, 21/02/1969.

Thompson, Christopher. 2011. "Modernizing for Trade: Institutionalizing Design Promotion in New Zealand." Journal of Design History no. 24 (3):223-239.

Van der Schueren, Jacques. 1959. "Boodschap van M.J. Van der Schueren." Supplément à L'Echo de la Bourse, 9 September, I.

Woodham, Jonathan. 2010. "Formulating National Design Policies in the United States: Recycling the "Emperor's New Clothes"?" Design Issues no. 26 (2):27-46.

Yagou, Artemis. 2005. "Unwanted Innovation. The Athens Design Centre (1961-1963)." Journal of Design History no. 18 (3):269-283. 
